\title{
14. VANE SHEAR STRENGTH MEASUREMENTS ON LEG 27 SEDIMENT
}

\author{
Karl Rocker, Civil Engineering Laboratory, NCBC, Port Hueneme, California
}

Vane shear strength of recovered sediments was measured during Leg 27 as part of the on-site physical properties testing program. The Navy's Civil Engineering Laboratory (CEL) miniature vane shear device, used previously by Mr. Homa Lee during Leg 19 (Lee, 1973c), was used to make the measurements.

\section{TEST PROCEDURES}

The tests were performed in the following manner. After each core section had been split, it was examined to determine if the sediment was sufficiently undisturbed and soft enough to test. If the sediment layers appeared relatively horizontal and there was sufficient material present, a test was run. This subjective examination eliminated most of the recovered sediments. However, in many cores from above 200 meters there was at least one short length, usually in the bottom section, where the sediment appeared relatively undisturbed. Although a variety of vane sizes was available, 188 of the 200 tests were run with the smallest of the vanes, which has 0.41 in. diameter $\times 0.50$-in.-high blades. A larger vane was used for the other tests, but it required a larger volume of undisturbed sediment, and the test was influenced more by boundary conditions (core liner and sediment surface). A sketch showing the smaller vane and other test dimensions to scale is shown in Figure 1.

The vane was inserted approximately $0.85 \mathrm{in}$. into the sediment and rotated in a counterclockwise direction at a rate of $8.3^{\circ} / \mathrm{min}$. After a peak torque value had been obtained, the sediment was remolded by rapidly rotating the vane approximately $720^{\circ}$ in the same direction until it was oriented in the same position as at the start of the test. A second measurement (remolded shear strength) was then made, also at the rate of $8.3^{\circ} / \mathrm{min}$ in the counterclockwise direction. Some variation in positioning of the vane in the core liner was necessary in punch core sections (surface core) due to the smaller liner diameter and in other cores where cutting produced asymmetrical section halves.

Reported shear strength is the maximum value reached during the test. All initial determinations exhibited distinct peak values, while the remolded test usually had no peak value, but increased at a decreasing rate. These forces were measured by a torque cell whose output was continuously monitored on a strip-chart recorder. Shear strength was computed by summing moments about the vane shaft, a standard procedure described by Brand (1967) and shown in Figure 1.

\section{SITE SHEAR STRENGTH SUMMARIES}

A summary of the shear strength testing at each of the five sites visited during Leg 27 is given below. Strength measurements are plotted versus depth for Sites 259 through 262 in Figures 2 through 5. Test data from the surface 20 meters are shown on an amplified scale in Figures 6 and 7.

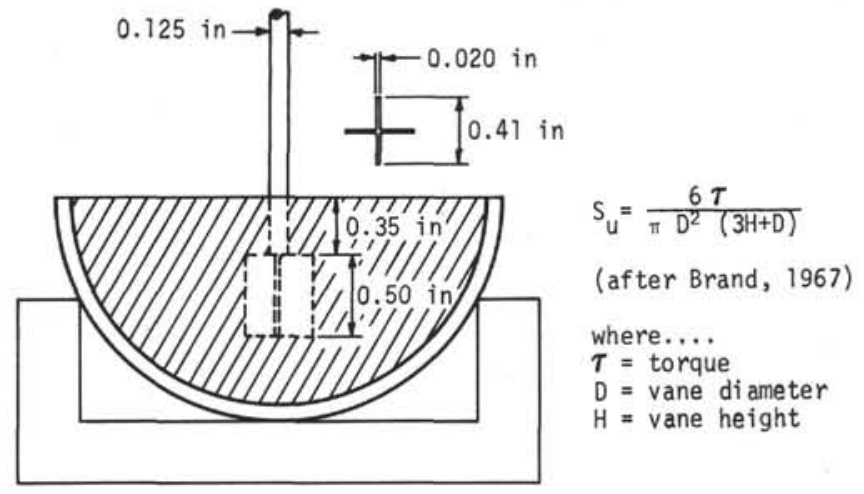

Figure 1. Vane shear measurement equipment and strength equation.

\section{Site 259}

Results from vane shear tests at 59 locations from 0.1 meters to 295 meters are presented in Figure 2. The data are distributed rather evenly through this range, as most cores had segments which were suitable for testing. Above 160 meters both nannofossil ooze and zeolite or cristobalite clay were tested. Below 160 meters only cristobalite and quartz clays were found. The measured shear strength drops initially from $0.06 \mathrm{~kg} / \mathrm{cm}^{2}$ at 0.14 meters to $0.04 \mathrm{~kg} / \mathrm{cm}^{2}$ at 2.5 meters. (All tests were on nanno ooze.) Shear strength in the zeolitic clay layer beneath this ooze increases through the layer to about $0.14 \mathrm{~kg} / \mathrm{cm}^{2}$ at 7.5 meters. Strength continues to increase over the next $100-150$ meters, at which point only a slight increase is discernible down to the limit of vane testing at 295 meters. It is difficult to define a pattern of strength behavior below 75 meters due to scatter of test values. This scatter is likely due to variations in sediment disturbance as well as to actual variations of sediment type.

Four residual pore pressure tests were run in conjunction with vane shear tests on Site 259 sediments. The pore pressure test is made adjacent to a vane shear test and is used to correct the vane measurement for sediment disturbance in order to obtain a more accurate estimate of in situ vane shear strength. The theory and description of the equipment as used onboard Glomar Challenger are described by Lee (1973a, 1973b). Equipment problems and the extraordinarily long time required to run each test resulted in these tests being discontinued. Although a few more residual pore pressure tests were run at other sites, the equipment problems increased and these data are not presented.

\section{Site $\mathbf{2 6 0}$}

Results from vane shear tests at 26 locations from 0.1 meters to 224 meters below the sea floor are presented in Figure 3. Shear data at Site 260 are meager due to poor 


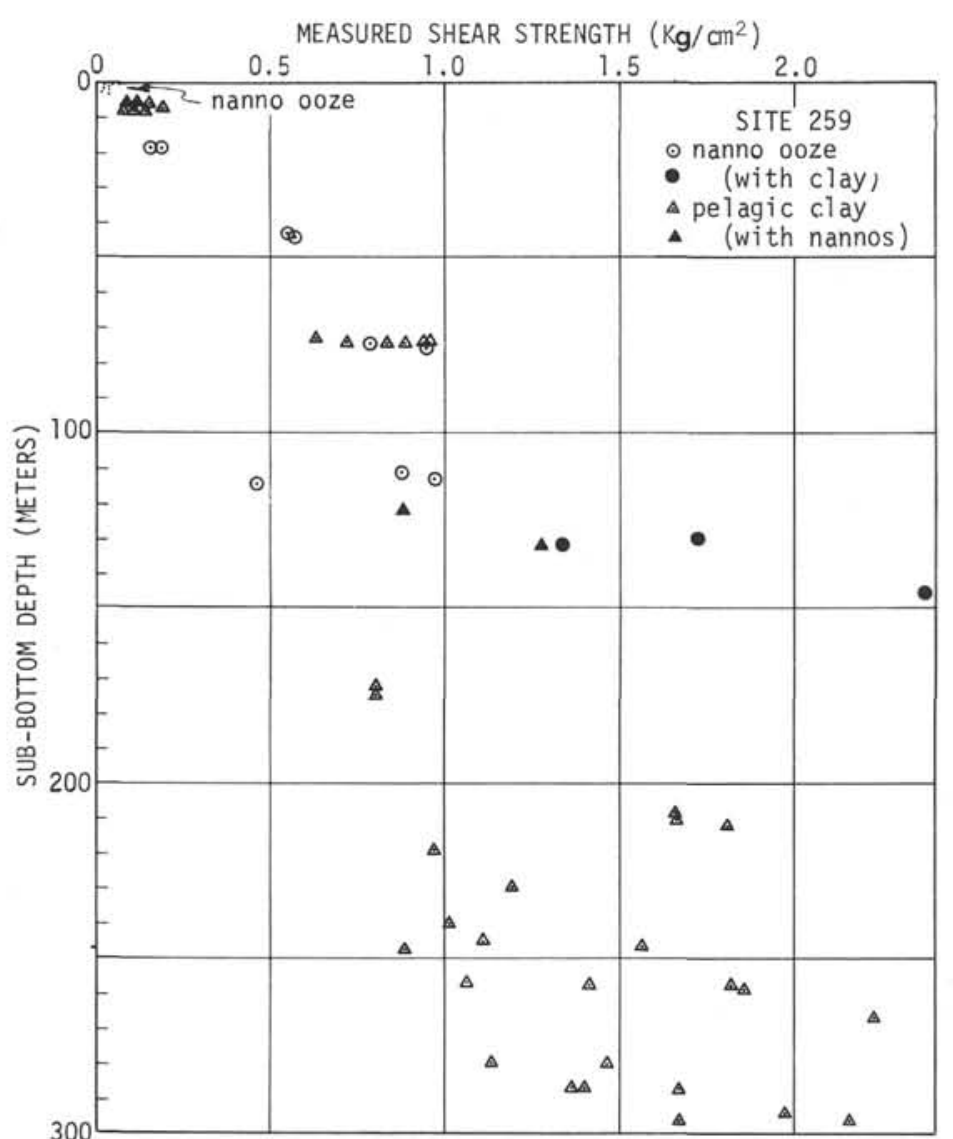

Figure 2. Vane shear strength measurements at Site 259.

recovery, a high disturbance in recovered sediments, and the small number of cores taken within the first 225 meters. In the surface core, radiolarian ooze and materials which varied in percentage of clay, Radiolaria, and nannofossils were tested. In nine tests from the surface 4 meters, shear strength varies from $0.01 \mathrm{~kg} / \mathrm{cm}^{2}$ to $0.05 \mathrm{~kg} / \mathrm{cm}^{2}$. Strength increases within this range, although scatter is considerable. Below the surface core, most tests were made in zeolite clay or foraminiferal nannofossil ooze. Strength at 46 meters increases only slightly to $0.10 \mathrm{~kg} / \mathrm{cm}^{2}$ (nanno ooze), and to $0.3 \mathrm{~kg} / \mathrm{cm}^{2}$ in the nanno ooze found at 99 meters. Most tests at these depths, however, were made in coarser detrital sediments (foraminiferal nannofossil ooze) and have a considerably lower measured strength. Tests on clay at 167,200 , and 224 meters show vane shear strengths considerably higher, between 1.4 and $1.7 \mathrm{~kg} / \mathrm{cm}^{2}$.

\section{Site 261}

Results from vane shear tests at 31 locations between 48 meters and 199 meters are shown in Figure 4. The tests are primarily from Core $3(47.5-57 \mathrm{~m})$, Core 4 (95$104.5 \mathrm{~m})$, and Core 8 (190-199.5 m). Testing at Site 261 was limited, as at the previous site, by poor recovery, high disturbance, and limited coring through the unconsolidated surface sediments. Nannofossil ooze in Cores 3 and 4 show shear strengths of about 0.25 $\mathrm{kg} / \mathrm{cm}^{2}$, while the pelagic clay has a higher strength,

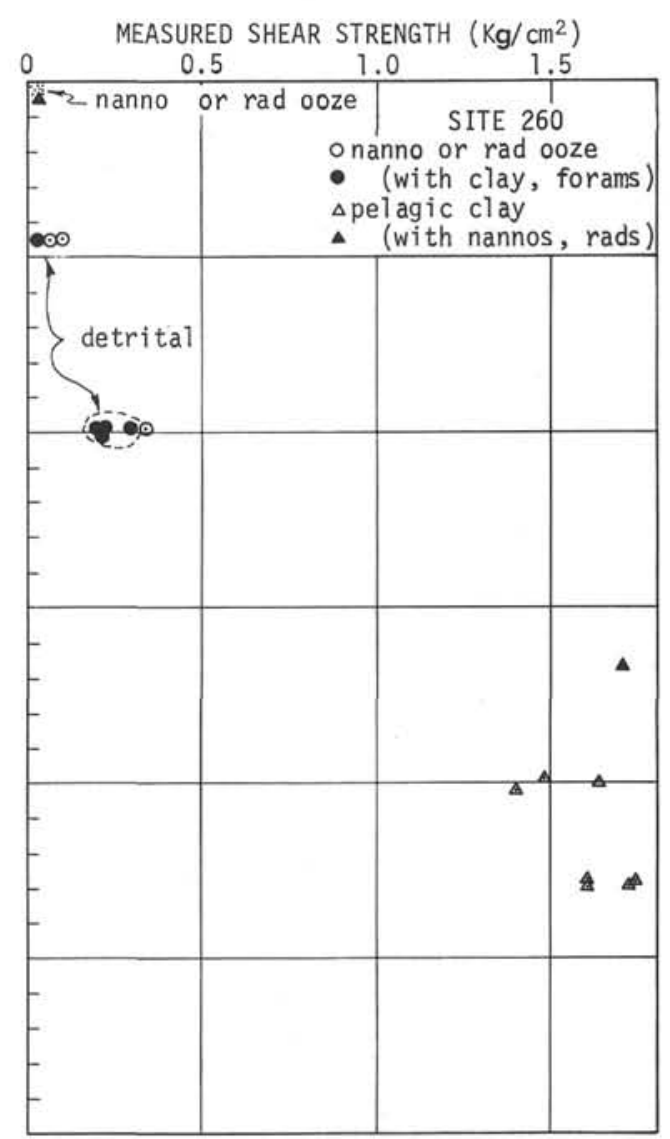

Figure 3. Vane shear strength measurements at Site 260.

about $0.5 \mathrm{~kg} / \mathrm{cm}^{2}$. The tests were made in alternating thin clay and ooze layers and show moderate scatter. (The two lowest strength clay tests were from a single layer, 3.5 meters from the others, and separated by a zone of high disturbance.) Shear strength of the nanno clay recovered from 162 meters is $1.45 \mathrm{~kg} / \mathrm{cm}^{2}$ and is higher again in the quartz and zeolite-bearing clay at 199 meters, although the data again show considerable scatter.

\section{Site 262}

Vane shear tests were run on sediments from nearly every core above Core 32 , at which point sediment strength exceeded equipment limitations. Results from tests at 84 locations between 0.6 meters and 299 meters are shown in Figure 5. Most tested sediments classify as a nannofossil ooze with varying but significant percentages of clay, Radiolaria, and foraminifera. Measured shear strength increases rapidly over the first 10 meters from $0.02 \mathrm{~kg} / \mathrm{cm}^{2}$ at 250 meters. Between 250 and 300 meters data show considerable scatter, with five of eight tests measuring shear strength above $2.3 \mathrm{~kg} / \mathrm{cm}^{2}$. Below 15 meters gas (methane) coming out of solution in the pore water caused visible sediment disruption in all cores. Although this disruption was sufficient to prevent sonic velocity determinations, it did not appear to seriously affect the vane shear tests. 


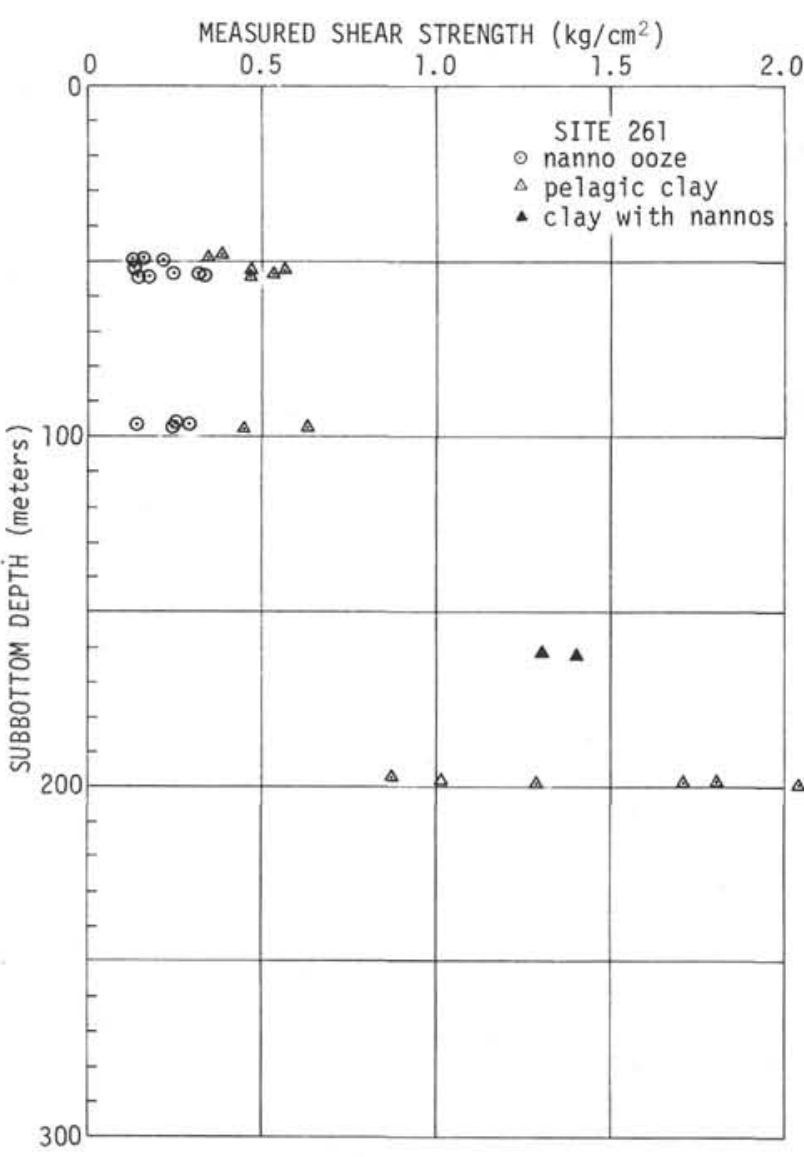

Figure 4. Vane shear strength measurements at Site 261.

\section{Site 263}

No shear data are presented for Site 263. Cores 1 and 2 were highly disturbed, and material recovered below Core 2 was too stiff for testing.

\section{Combined Leg 27 Shear Strength Data}

The sites visited during Leg 27 are presently separated from each other by at least one major topographic barrier. Although the depositional environments have likely shared some characteristics and these barriers may not have always been present, there are also likely to have been significant differences during all periods of sediment accumulation. The pelagic clay and nannofossil ooze sediments identified and tested for shear strength at Sites 259 through 262 thus probably differ from each other significantly, despite sharing the same compositional name. The test data have been separated into these two major sediment types encountered during Leg 27 and plotted on that basis in Figures 6 and 7. (Test data from the surface 20 meters are shown at an amplified scale.) The data were plotted in this manner to compare site-to-site variations with those observed in the same material at each site.

In Figure 6, the variation in strength below 20 meters is dominated by the Site 262 sediment data which have high percentages of clay, Radiolaria, and foraminifera. The relatively few other tests, at 50 and 100 meters on pure nannofossil ooze, show lower strengths with considerable scatter. Above 20 meters, however, results

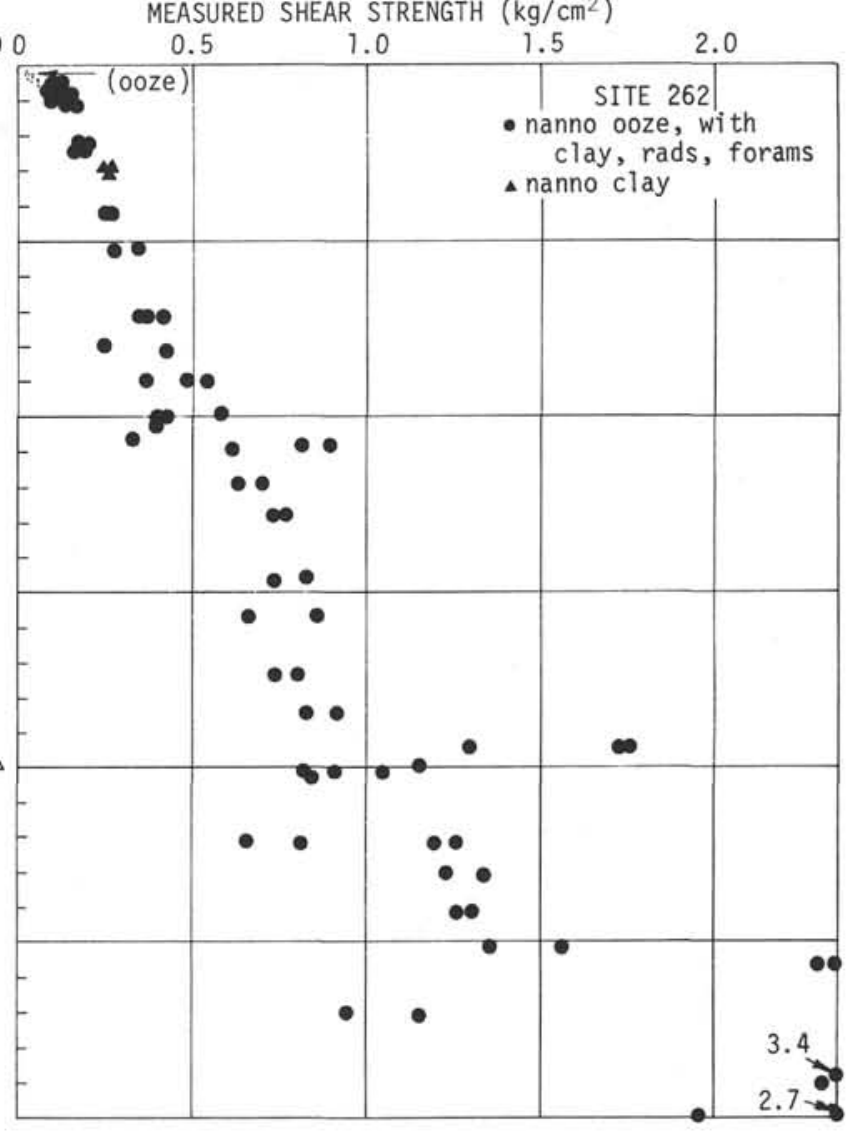

Figure 5. Vane shear strength measurements at Site 262.

from the three sites tested (Site 261 is excluded) are consistent. Strength near the surface is constant, or decreases, for 1 to 2 meters before increasing at a constant rate. Sensitivity is constant below the surface where many tests yielded very high sensitivities.

Pelagic clay test data in Figure 7 are primarily from Sites 259, 260, and 261. Strength increases almost linearly for the first 200 meters. Below 200 meters the data scatter is considerable, and a strength increase cannot be identified. Few Leg 27 tests were run on clay in the surface 20 meters. Sensitivity is constant down to 200 meters except for several high values at the surface. Below 200 meters most data are from Site 259, and the sensitivity is considerably higher but shows much scatter.

\section{COMBINED LEG 27 VOID RATIO DATA}

At each location where a vane shear test was made, a syringe sample was taken. The syringe test may be used to estimate water content and wet-bulk density. Void ratio can be estimated from these data by assuming a grain density and complete saturation. The void ratios computed in this manner from syringe sample data are shown in Figures 8 and 9 for nannofossil ooze and pelagic clays recovered during Leg 27. Overburden stress at the location of each test was computed from a density profile estimated from other Leg 27 density data. The Site 262 data on nannofossil ooze with high percentages of clay, Radiolaria, and foraminifera are shown in Figure 10. They have been separated because 


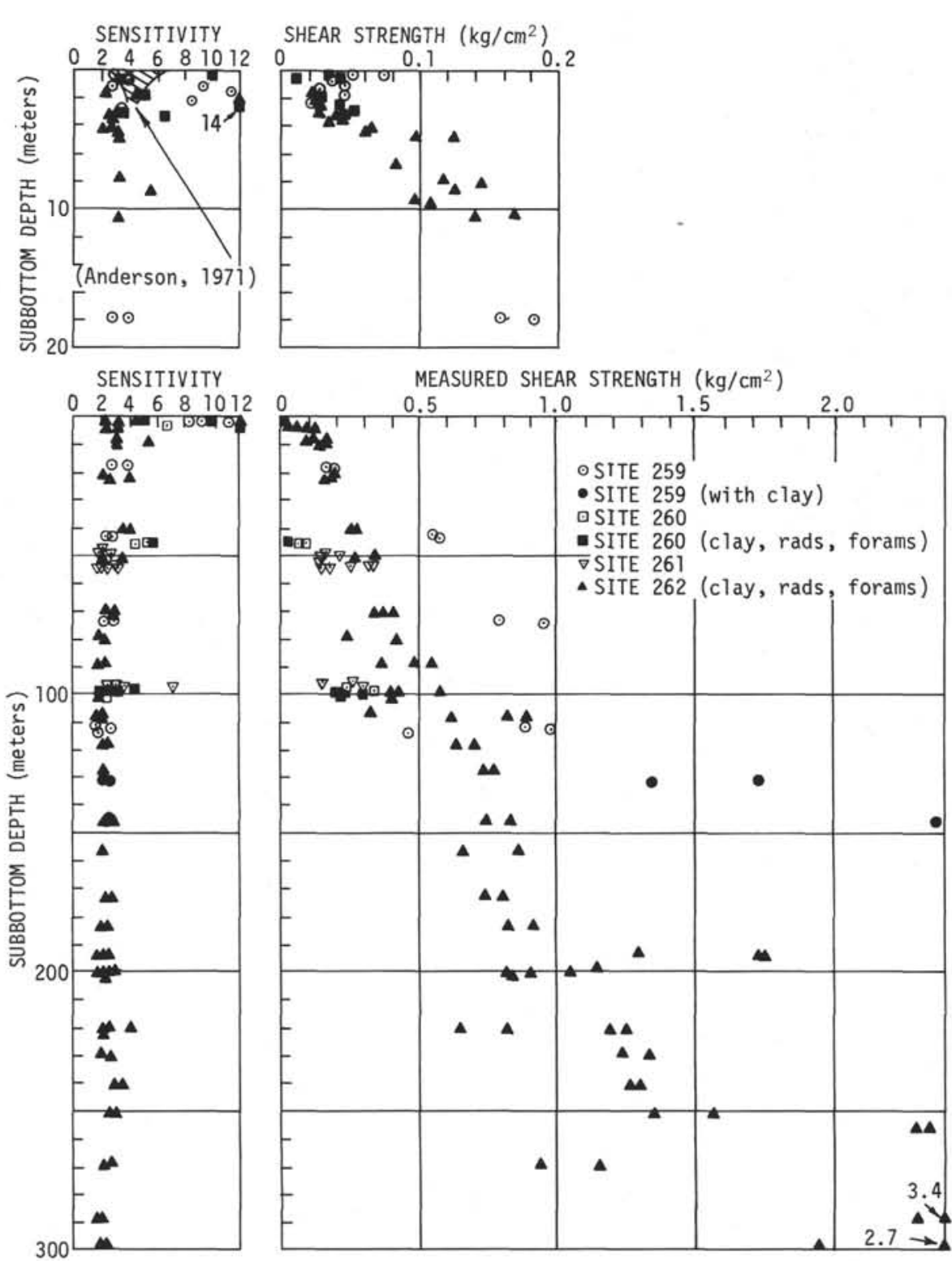

Figure 6. Measured vane shear strength and sensitivity of nanno ooze recovered during Leg 27.

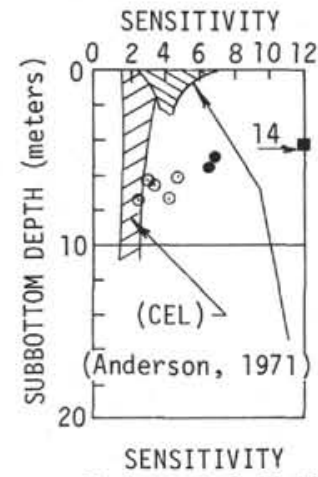

SHEAR STRENGTH $\left(\mathrm{kg} / \mathrm{cm}^{2}\right)$
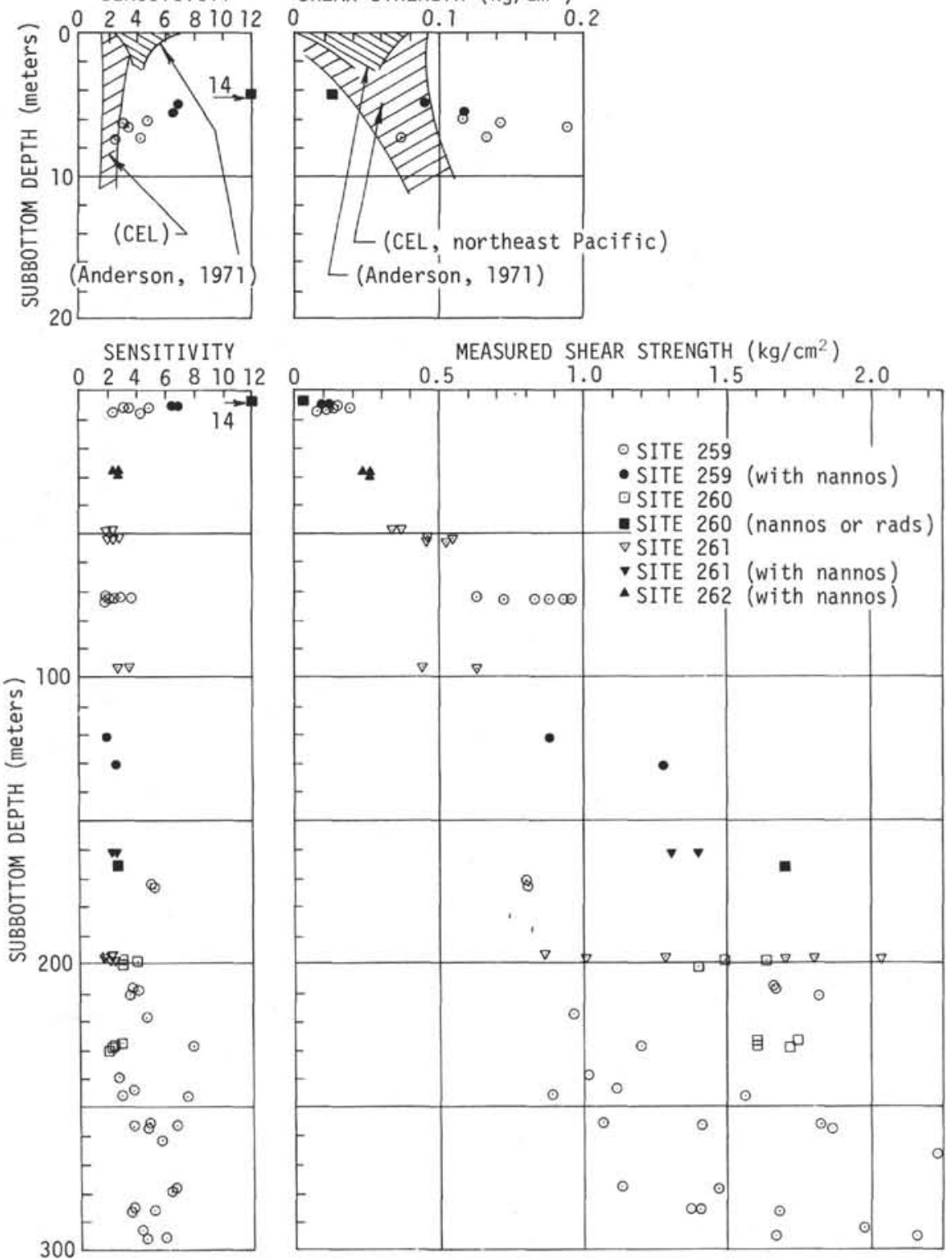

Figure 7. Measured vane shear strength and sensitivity of pelagic clay recovered during Leg 27. 


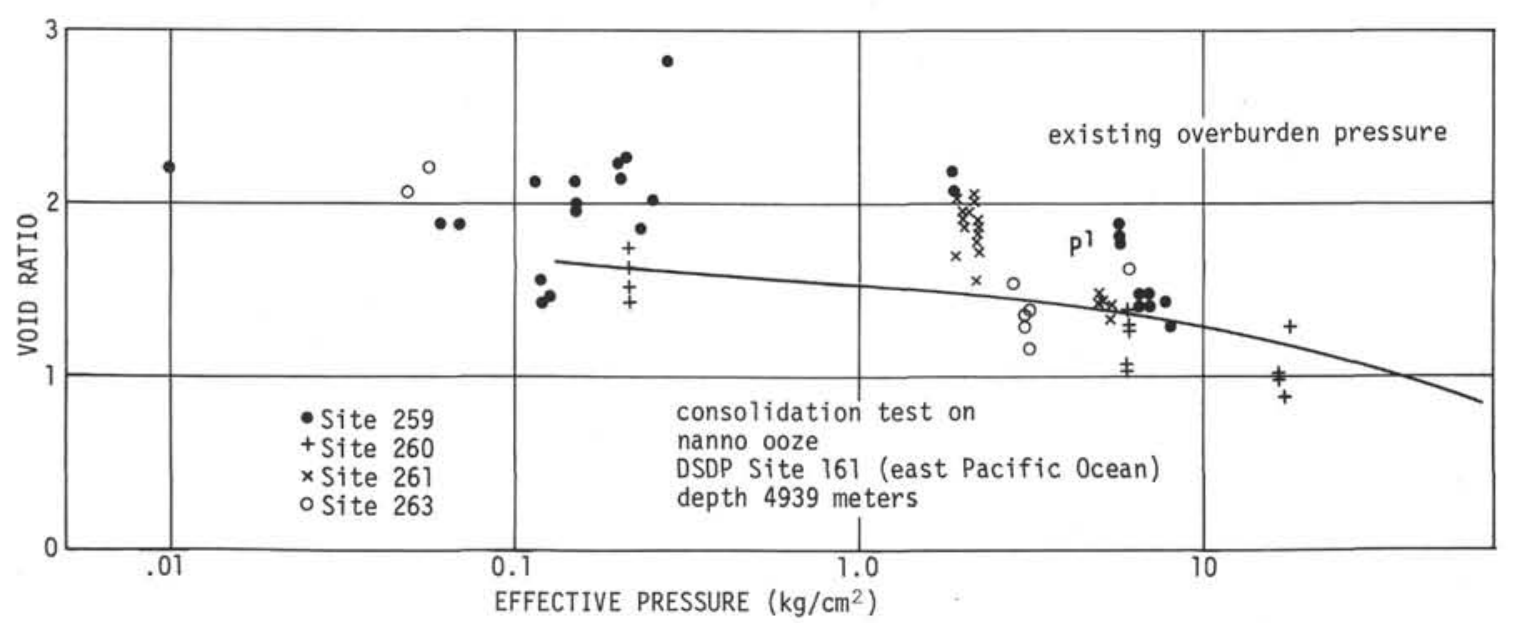

Figure 8. Variation of void ratio with existing overburden pressure in nanno ooze recovered during Leg 27.

of slightly higher void ratio at an equivalent overburden stress. Consolidation curves for sediments similar to those of Leg 27 are also shown in Figures 8 and 9. Curves from DSDP Sites 160 and 161 were published by Keller and Bennett (1973). Other east Pacific Ocean curves are from CEL (unpublished) sources.

\section{COMPARISON OF LEG 27 TEST CONDITIONS WITH OTHER DEEP-SEA TESTS}

DSDP test results differ from other data reported in the literature because of differences in the testing procedure and in the disturbance level of the tested sediments. The test procedure used has the following characteristics which are likely to be different from many of the other tests made on deep ocean sediment:

a) Measurements made on split DSDP sections average strength from the horizontal and vertical directions in an unusual manner.

b) The primary vane used is very small and the diameter is approximately equal to the vane height.

c) The test is made in a shipboard laboratory immediately after the sample has been retrieved.

d) Vane speed is $8.3^{\circ} / \mathrm{min}$.

e) Remolding of the sediment between the initial and remolded test is done by rapid rotation of the vane (previously described).

Vane shear measurements are normally made by inserting the vane in a direction perpendicular to the in situ horizontal bedding planes. Bottom-resting platforms, drill ships equipped with down-hole vane shear capability, and most laboratory tests are run in this manner, while the shipboard DSDP test is made by inserting the vane in a direction parallel to the in situ horizontal bedding planes. If the soil were perfectly isotropic, the measured strengths would not be significantly different. Most soils, however, are sufficiently anisotropic to exhibit significant strength differences in the horizontal and vertical directions. This is reflected in vane shear results in proportion to the amount of shearing force mobilized in each plane. In one series of tests on normally consolidated sensitive clays (Aas, 1965) the ratio of horizontal to vertical shear strength has been shown to vary between 1.5 and 2.0. In situ testing devices normally use vanes with a height-todiameter ratio of 2 or more. In these cases over $75 \%$ of the shearing surface is then in a vertical plane. For the DSDP tests most shear occurs on planes between the vertical and horizontal where strength is likely to be between the two extremes. DSDP test results should thus reflect more of the (higher value) horizontal shearing resistance.

Use of very small vanes in DSDP and other laboratory tests may result in more data scatter than is recorded by in situ testing. A significant number of the DSDP tests were run in layers of sediment which are thinner than some in situ test vanes are long. The longer in situ vanes will average strengths of the layers they encounter and thus measure less variation.

The post-sampling time at which the shear measurement is made has a large effect on its accuracy and the value of the measurement. After the sediment is initially disturbed by coring, considerable further disturbance is imposed by subsequent handling and during storage. The measurement of sediment properties becomes less representative of the in situ condition as the time between coring and testing increases. If the sediment water content and chemical properties do not change, further disturbance with time will lower the measured shear strength. Changing the water content, however, can either decrease or increase strength depending on whether water content increases or decreases. If in situ testing cannot be done, at-sea testing (immediately after the core has been retrieved) produces the most accurate property value. Most strength values reported in the literature are determined in a shorebased laboratory on sediment which has been stored on ship and on shore for at least several days and most likely for several weeks. While a few vane measurements have been made in situ with specialized equipment, such as that described by Demars and Taylor (1971); Doyle et al. (1971); and Richards et al. (1972), this equipment is relatively expensive and time consuming to use to obtain a large quantity of data. 


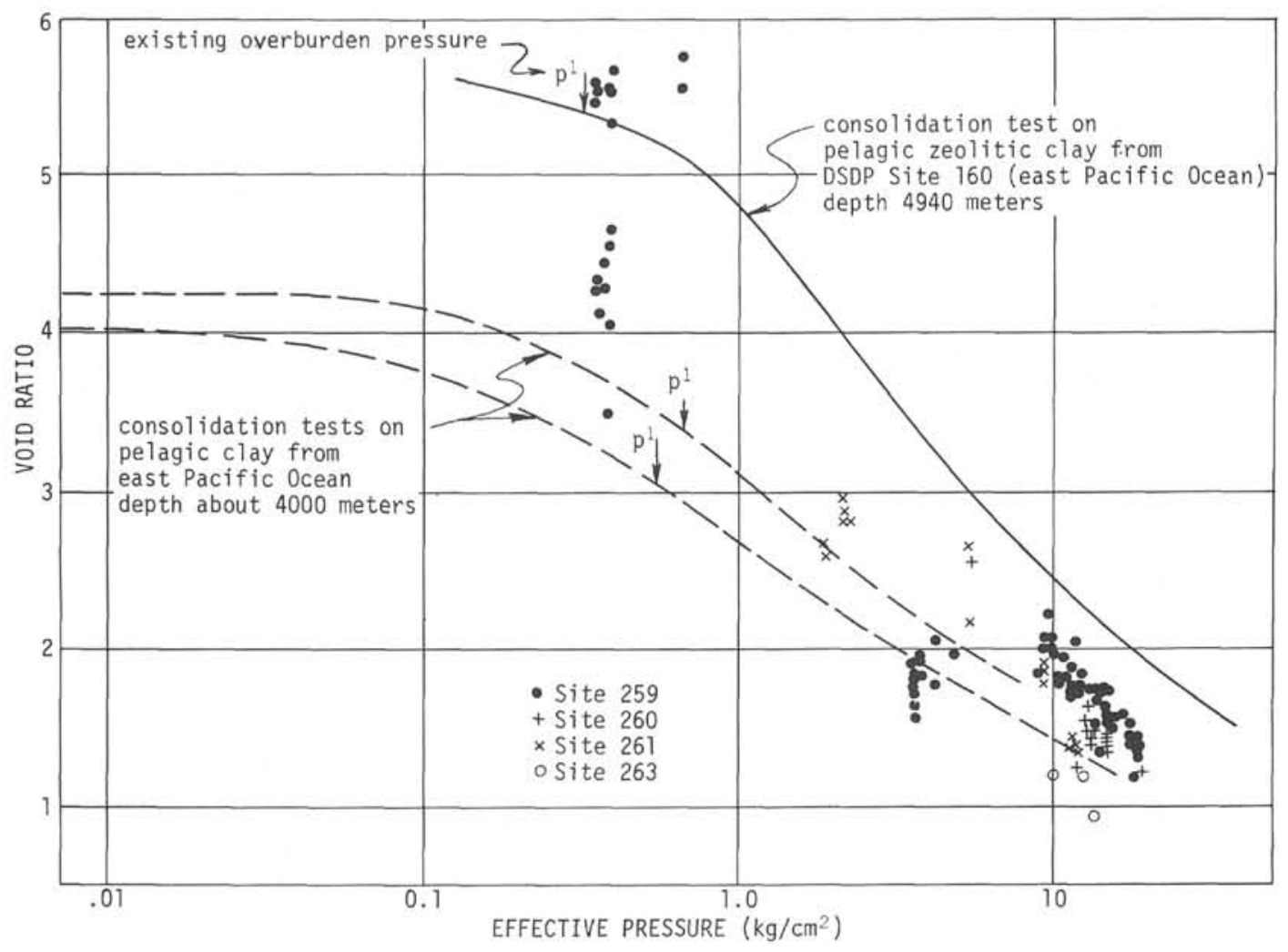

Figure 9. Variation of void ratio with existing overburden pressure in pelagic clay recovered during Leg 27.

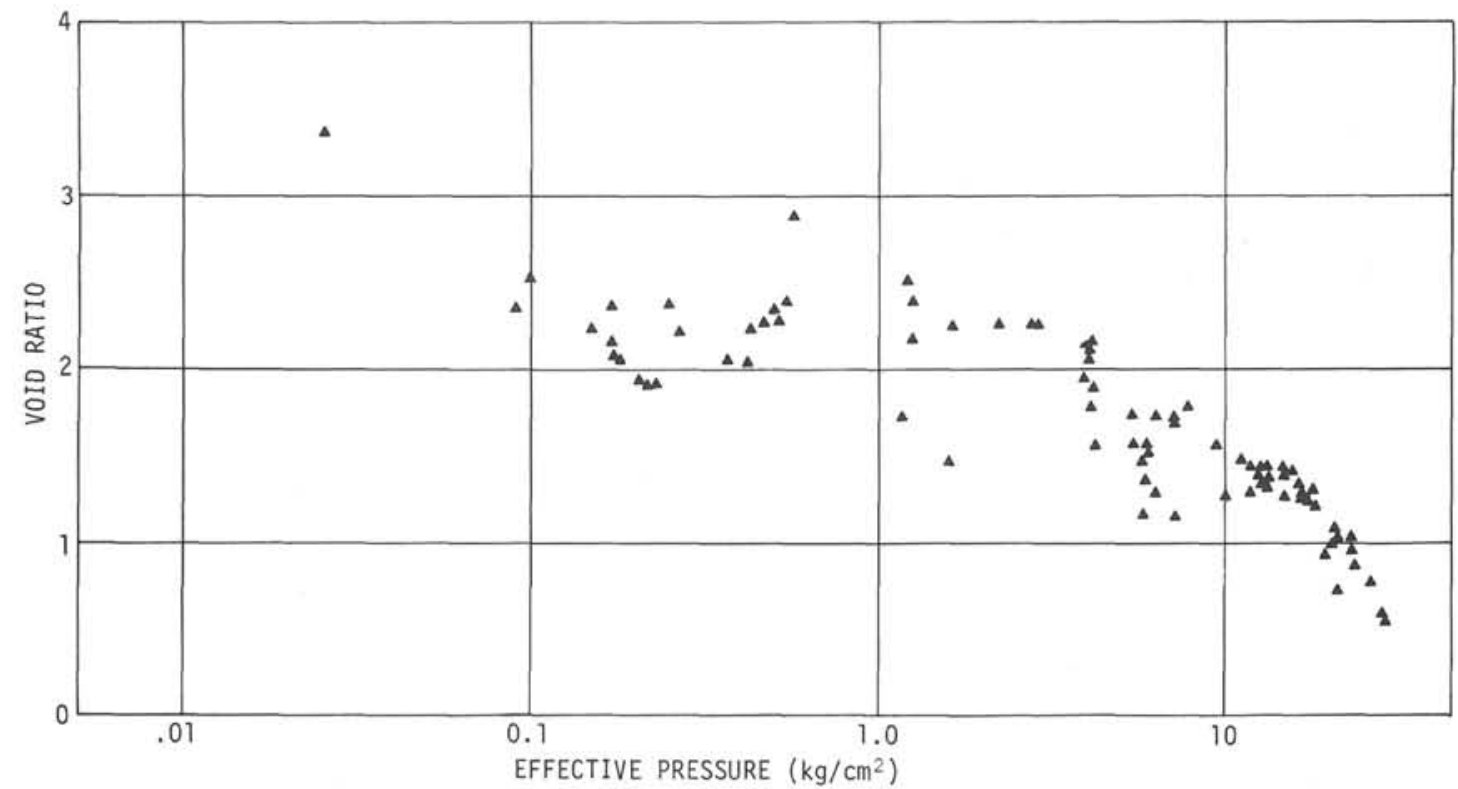

Figure 10. Variation of void ratio with existing overburden pressure in Site 262 sediments (clay-, foram-, or rad-rich nanno ooze). 
Vane speed can have a significant effect on test results. The vane shear test assumes the tested material is cohesive, and no sediment drainage occurs during shear. However, even when these conditions are apparently met, the rate of rotation will influence the measurement. Anderson (1971) summarizes results from three studies showing an increase in strength as the vane rotation rate increases from $2 \% \mathrm{~min}$. to $6^{\circ} / \mathrm{min}$. to $30^{\circ} / \mathrm{min}$. The strength increase is larger for sediments with higher water contents and is larger for the initial test than for remolded tests.

The previously described method of remolding the sediment is different from some other methods used. In some of these the sediment is completely remolded with a spatula and a second vane test is run immediately or after a specified time interval. In others, the remolding is also done by rapid rotation of the vane, but the second test is not made until a specified time has elapsed. Differences in remolding technique can result in different remolded strength values even when the sample does not take on or lose moisture. The remolding method used was chosen for convenience (limits time per test and minimizes distortion of recovered DSDP sediments) and because the technique is similar to actual field conditions where continuous shearing occurs along an established failure plane.

Although DSDP has concentrated on minimizing disturbance in recovered materials, even the highest quality core segments display considerably more disturbance than is found in better examples of the more common techniques used to obtain sediment, such as gravity or piston coring. The disturbance in DSDP cores also varies more over the length of the core and has larger variations between adjacent sediments of a different stiffness. DSDP disturbance is comparatively high because corer dimensions and drilling methods were designed for maximum penetration in deep consolidated sediments and hard rock and do not function well in soft sediments. Several problems which contribute to the high disturbance are (1) lack of a tapered cutting edge on the corer, (2) very high ratio of bit outer diameter to core liner inner diameter, (3) high ratio of core length to core liner inner diameter, and (4) washing action from drilling jets.

\section{COMPARISON OF LEG 27 VANE SHEAR DATA WITH OTHER DEEP SEA DATA}

The value of the DSDP vane shear test is related to how well the test data represent in situ shear strength. Although these cannot be quantitatively compared, some measure of quality can be made by examining the test conditions and sediment behavior and comparing this to other vane shear tests made on similar soils. ( $A$ quantitative comparison would require in situ vane shear tests or tests on a core of known high quality taken adjacent to the DSDP core, neither of which is available.) Unfortunately, little other data exist for comparison with Leg 27 tests. Deep ocean sampling utilizes spade (box) corers for relatively undisturbed surface samples and gravity or piston cores for deeper penetration. These deeper penetrating corers are more disturbed and are seldom capable of retrieving more than the surface 10 meters or so of sediment. Only a few "long piston corers" are capable of recovering 30 or 40 meters of sediment.

In situ testing has an even more limited historical background. In the past the desire for in situ testing in the deep ocean has been limited. Few devices exist which can operate in ocean areas deep enough to be characterized by surficial pelagic clay or ooze deposits. Down-hole vane shear tests, currently the only means to penetrate deeply into sediment, can be run only at comparatively shallow water depths. Bottom-resting platforms and submersible carriers are capable of only 1 to 3 meters of penetration and also have not been used to test pelagic clay or ooze. (Most in situ devices currently have operational or design restrictions, which prevent exploration below 2,000 to $3,000 \mathrm{~m}$.)

A limited amount of vane shear data from tests on sediment similar to those tested during Leg 27 has been published. A large number of shipboard vane shear tests were run by Anderson (1971) on sediments recovered from the southwest Pacific and eastern Indian oceans by gravity corers. Sediments were identified by physiographic province location only (continental terrace, abyssal plain, or abyssal hill) and by a large quantity of accompanying properties test data which serve to better classify the soil type. The sediments were mostly from the surface 1.5 meters, although some were as deep as 2.5 meters. A large number of tests have also been run (CEL, unpublished) on pelagic clay recovered from the northeast Pacific Ocean basin by a piston corer. Tests on these sediments were from the surface 11 meters in several widely spaced cores. Both sets of tests utilized similar techniques and equipment and were made by personnel from CEL. These data are shown in Figures 6 and 7 as zones into which all the data points fall. Unfortunately, the overlap of Leg 27 data with the others is not great. The majority of shallow Leg 27 information is from ooze or ooze-based sediments, while most of the other data are from tests on pelagic clay.

A comparison of data can be made on the basis of measured initial and remolded shear strengths. It may be assumed, based on visual observations of layer distortion, that the DSDP cored sediment is more highly disrupted during sampling than are the other sediments. If the sediments were of the same strength, this higher level of coring disturbance would be expected to be reflected in the strength measurements. Furthermore, if the disturbance did not reduce the sediment water content, then Leg 27 measured initial shear strength values should be lower. Figure 7, however, shows the Leg 27 strengths to be higher than the north Pacific data at equivalent depths. They are likely to be higher also than Anderson's east Indian and southwest Pacific data, although the tests were not made at the same depth as were the Leg 27 data. (The strengths reported by Anderson all lie within the north Pacific data band.) No strength comparison has been attempted between oozes because of difficulty in separating ooze from other low void ratio sediments in the Anderson data.

Remolded strength is compared on the basis of its relation to the initial shear strength. The ratio of the initial to remolded strength is commonly called sensitivity and is a good indicator of the degree of disturbance. 
For a particular cohesive sediment a higher level of disturbance will cause a lower initial strength and thus a lower sensitivity. The sensitivity for Leg 27 and the other tests on pelagic clay are shown in Figure 7. The Leg 27 sensitivities are higher than those values from the north Pacific. In this comparison, however, the Anderson data are also higher than that from the north Pacific over equivalent depths. (A compairson of ooze sensitivity is possible because all the Anderson low void ratio values fell in the narrow range shown on Figure 6.) There is considerable scatter in the shallow ooze sensitivities, with some Leg 27 values falling above and some below the Anderson tests.

A comparison of strength buildup during the vane shear test may be made between Leg 27 and the north Pacific tests. Both test sets were run at the same rotation rate with the same testing equipment and approximately the same size vane. The characteristic behavior during the initial shear test is a rapid buildup of resistance until a peak value has been obtained, followed by a moderate decrease in resistance. (The decrease is a result of shear taking place within sediment which has been remolded by one of the other vane blades.) If the sediment being tested is highly disturbed, the plot of shearing resistance versus angular displacement will be more flat and may not have a distinct peak. After the sediment is purposely disturbed by rapid vane rotation, the remolded vane test (normally) shows no peak. Of the Leg 27 tests compared, most displayed resistance versus displacement curves approximately the same or only slightly more flat than those of the north Pacific tests (considered reasonably good quality cores). Although several of the Leg 27 curves fell well below the average, there were a number of north Pacific curves that likewise were anomalously low. This comparison, however, cannot be conclusive because it is not known if the shear strength buildup should be the same for similar sediments at the same level of disturbance.

In conclusion, these results indicate that the Leg 27 pelagic clay sediments are either stronger or less disturbed at the time of testing than are the clays from the other areas. Insufficient knowledge of strength variation in pelagic clays of similar composition prevents the resolution of this point. Conclusive statements cannot be made on the ooze data. While there is little apparent evidence to suggest why the Leg 27 sediments would be stronger (in situ), there are strong reasons to suspect they should have undergone a higher level of disturbance.

One of the reasons for performing vane tests onboard the Glomar Challenger was to investigate the ship's unique capability as a method for obtaining this type of data. While the data comparisons do not answer many questions about the test, they offer no basis to suggest that the high level of disturbance should prevent meaningful vane shear testing of DSDP samples.

\section{REFERENCES}

Aas, G., 1965. A study of the effect of vane shape and rate of strain on the measured values of in situ shear strength of clays: Internatl. Conf. Soil Mechanics Foundation Eng. 6th Proc., v. 1, p. 141-145.

Anderson, D. G., 1971. Strength properties of some Pacific and Indian Ocean sediments: U.S. Naval Civil Engineering Lab. Tech. Note N-1177.

Brand, E. W., 1967. The vane shear test and its use for strength measurement of cohesive soils: RILEM Bull. No. 36, p. 191.

Demars, K. R. and Taylor, R. J., 1971. Naval seafloor soil sampling and in-place test equipment: A performance evaluation. U.S. Naval Civil Engineering Lab., Tech. Rept. R-730.

Doyle, E. H., McClelland, B., and Ferguson, G. H., 1971. Wire-line vane probe for deep penetration measurements of ocean sediment strength: Preprints Offshore Tech. Conf., v. 1, p. 21-32.

Keller, G. H. and Bennett, R. H., 1973. Sediment mass physical properties-Panama Basin and Northeastern Equatorial Pacific. In van Andel, T. H., Heath, G. R. et al., Initial Reports of the Deep Sea Drilling Project, Volume 16: Washington (U.S. Government Printing Office), p. 509.

Lee, H. J., 1973a. Engineering properties of some North Pacific and Bering sea soils: U.S. Naval Civil Engineering Lab. Tech. Note N-1283.

Lee, H. J., 1973b. In-situ strength of seafloor soil determined from tests on partially disturbed cores: U.S. Naval Civil Engineering Laboratory. Technical Note N-1295.

Lee, H. J., 1973c. Measurements and estimates of engineering and other physical properties, Leg 19. In Creager, J. S., Scholl, D. W., et al., Initial Reports of the Deep Sea Drilling Project, Volume 19: Washington (U.S. Government Printing Office), p. 701.

Richards, A. F., McDonald, V. J., Olson, R. E., and Keller, G. H., 1972. In-place measurement of deep sea soil shear strength: Underwater soil sampling, testing, and construction control, ASTM STP 501, Am. Soc. Testing Materials, p. 55-68. 